\title{
Did we Constrain Managers' Attempts to Manipulate Earnings: Insights from the Relevant Literature
}

\author{
Medhat N. El Guindy \\ Tanta University, Faculty of Commerce, Egypt \\ Currently, American University in Dubai, School of Business Administration, UAE
}

\section{Mohamed Z. Yassin}

Tanta University, Faculty of Commerce, Egypt

Currently, University of Bahrain, College of Business Administration, Bahrain 


\title{
Did we Constrain Managers' Attempts to Manipulate Earnings: Insights from the Relevant Literature Medhat N. El Guindy
}

Tanta University, Faculty of Commerce, Egypt Currently, American University in Dubai, School of Business Administration, UAE

\section{Mohamed Z. Yassin}

Tanta University, Faculty of Commerce, Egypt

Currently, University of Bahrain, College of Business Administration, Bahrain

\begin{abstract}
Since the numbers game speech by Levitt (1998), earnings management is becoming one of the most cited accounting research areas. The objective of this paper is to review the main themes highlighted in the relevant literature. Studies provided some contradicting points of views regarding earnings management definition, incentives, and techniques. Earnings management, in general, tends to be undesirable as it distorts the financial reporting process and subsequently leads to lower earnings quality. Therefore, regulators have invested time and effort seeking solutions to this problem (Examples include regulations regarding auditor independence, audit firm tenure, auditing standards, and accounting standards). In addition, accounting and auditing research investigated factors and mechanisms, which lead to mitigate or constrain earnings management. Earnings management is classified into accruals earnings management, real earnings management, and classification shifting earnings management. The focus of this paper is on earnings management mitigation. Different studies provided some evidence on the role of each of investor protection, corporate governance, external auditing, and accounting standards in mitigating earnings management.
\end{abstract}

Keywords:

Earnings management, auditor fees, corporate governance, principles-based standards. 


\section{INTRODUCTION}

Since the numbers game speech by Levitt (1998), earnings management is becoming one of the most cited accounting research areas. The objective of this paper is to review the main themes highlighted in the relevant literature. Research about earnings management covers areas such as incentives to manage earnings, estimating discretionary accruals and variables lead to mitigating earnings management.

Earnings management is an element of the broader concept of earnings quality, which in turn can be viewed as part of accounting quality in general. There are many attempts to define earnings management. Healy and Wahlen (1999, , P. 368) presented one of the most widely accepted earnings management definitions as follows:

"Earnings management occurs when managers use judgment in financial reporting and in structuring transactions to alter financial reports to either mislead some stakeholders about the underlying economic performance of the company or to influence contractual outcomes that depend on reported accounting numbers".

Moreover, Schipper (1989a, , P. 92) defines earnings management as follows:

"Earnings management is purposeful intervention in the external financial reporting process, with the intent of obtaining some private gain (as opposed to say, merely facilitating the neutral operation of the process)".

Fields et al. (2001, , P. 260) suggest that the following definition:

"Earnings management occurs when managers exercise their discretion over accounting numbers, with or with out restrictions. Such discretion can be either firm value maximizing or opportunistic".

Prior literature discussed two types of earnings management: opportunistic and informative. Opportunistic earnings management occurs when managers use judgments to mislead stakeholders to achieve some private gain. Examples of private gain include compensations contracts (Healy 1985). Considering the case of Enron, managed earnings are not desirable if it distorts the underlying truth of operations. On the other hand, earnings management may be viewed as informative when used by managers as a means to communicate their private information and expectations about the firm. In this case, discretions used to convey firm's future prospects and earnings management is value increasing to shareholders and other stakeholders (Watts and Zimmerman 1986, 1990). 
Ronen and Yaari (2008), based on an extensive literature review, view earnings management as 'white' if it is just taking advantage of accounting treatments' flexibility to communicate managers' private information on expected future cash flows. In addition, they viewed it as 'grey' if it involves a choice of accounting treatment or method that is opportunistic in a way that leads to maximize management's benefits only. On the other hand, they viewed it as 'black' if it involves the practice of using tricks to misrepresent financial reports or leads to reduce the transparency of them.

All of the above definitions agree on the main issues of how management of the firm may use judgment to intervene in the financial reporting process to alter financial results but the definitions did not specify whether earnings management is conducted in accordance with accounting standards or violating them. Some authors argue that earnings management differs from fraud as fraud is done by violating accounting standards (Dechow and Skinner 2000). However, Nelson et al. (2002) argue that earnings management can be separated into the following two types: within GAAP Earnings management and outside GAAP Earnings management.

Meanwhile, some authors argue that earnings management can be perfectly acceptable. For instance, Fields and Keys (2003) argue that earnings management occurs "if management did not cross the line into grey areas". However, we argue that this will be just the normal decisions of management in running the business and that is not considered earnings management. Added to that, Parfet (2000) argues that earnings management can be separated into good and bad earnings management where the good earnings management does not lead to harming stakeholders but to benefit them.

To sum up, all the above definitions can be combined to reflect different views about earnings management as follows: Earnings management is all accounting practices undertaken by the management of the firm with the objective of affecting the net income figure to mislead some stakeholders whether these practices are undertaken in accordance with accounting standards (GAAP) or by violating them. This definition is developed based on the following reasons. Firstly, it has to be accounting practices so as to exclude real earnings management which we argue is just managerial decisions and can't be seen in this context. Secondly, the objective is affecting net income in any direction whether to increase or decrease because both ways result in lowering earnings quality. Thirdly, earnings management does not necessarily mislead every related party. Finally, we argue that earnings management can be done whether by using or abusing accounting standards and by violating them as any attempt to mislead some stakeholders is undesirable and should be mitigated. Nelson et al. (2003) provide empirical evidence which supports this idea by examining how earnings 
management is conducted based on the experience of 515 auditors who identified a number of attempts ranging between within GAAP to violating them. The rest of this paper is organized as follows; section two discusses theoretical explanation of earnings management. Section three illustrates earnings management incentives. In addition, section four explains earnings management techniques and types. Furthermore, section five reviews the relevant literature about earnings management mitigation. Finally, section six concludes.

\section{EARNINGS MANAGEMENT: THEORETICAL EXPLANATION}

The accounting literature provides two opposing points of view regarding the separation of ownership and control: agency theory and stewardship theory. Agency theory can be viewed as a relationship between the principal (owners or stockholders) and agents (managers). As the owners lack the required knowledge to run the business, they hire professional management to run the daily operations of the firm. Despite the claimed benefits of appointing professional managers to run the company, this separation of ownership and control may result in a potential conflict of interests. For example, owners are interested in firm's value maximization and long-term performance where managers might be interested at maximizing their own interests in term of compensations and bonuses. Consequently, a moral hazard problem emerges which leads managers working against the interests of their principals and attempting to alter financial reporting in such a way that maximizes their own interest. Therefore, earnings management can be viewed as one of the agency costs. In addition, other agency costs include hiring an external auditor to monitor the practices of management as part of monitoring costs (Jensen and Meckling 1976; Fama and Jensen 1983; Watts and Zimmerman 1986, 1990).

On the other hand, stewardship theory takes a different point of view. Under stewardship theory, principals (owners)-agents (managers) interests are aligned. In other words, stewardship theory defines situations in which managers are not motivated by individual goals, but rather are stewards whose motives are aligned with the objectives of their principals (Davis et al. 1997). Advocates of stewardship theory (Abed et al. 2012; Chi et al. 2015; Muth and Donaldson 1998; Prencipe et al. 2008; Schipper 1989b) suggest that agents are trustworthy and good stewards. Therefore, opportunistic earnings management is unlikely to occur according to this view. However, informative earnings management might exist and can be explained by the potential benefits to owners because of this type of earnings management. Furthermore, under the stewardship theory, monitoring is not required. On the contrary, we need an environment that helps managers exercising their full power and authority to best serve owners' interests. 


\section{EARNINGS MANAGEMENT INCENTIVES}

Accounting research in the area of earnings management was primarily focused on why earnings management is done (e.g. Kaplan 1985). In fact, companies manage earnings for a variety of reasons. One of the most important and widely spread reasons is management compensation whether it is cash bonus or stock options (Healy and Wahlen 1999). Healy (1985) finds evidence that managers uses discretionary accruals to maintain their incentives at an acceptable level. They can do that by decreasing net income when they are above maximum compensation or increasing net income if they are between the maximum and minimum compensation to get the maximum compensation allowed or even decreasing net income if it is impossible to reach the minimum for this year's compensation.

Moreover, management may engage in earnings management practices to meet debt covenants contracts. As debt ratios increase, management is more likely to use discretionary accruals to increase income especially when financial ratios touch those limits specified in debt contracts (e.g. Frantz 1997; Jaggi and Picheng 2002; Saleh and Ahmed 2005). In addition, the political cost incentive is also one of the important motivations for management. For instance, Jones (1991) provides evidence that companies manage earnings negatively to decrease net income during the period preceding examining companies' records for import relief, and Cahan (1992) provides evidence for the same behavior during antitrust investigations.

In addition, some studies have also examined whether companies manage earnings in periods prior to equity offerings. Results indicate that firms report positive discretionary accruals prior to seasoned equity offers and initial public offers (Shivakumar 2000; Teoh et al. 1998a; Teoh et al. 1998b). Also, tax advantages is another motivation for companies as they may attempt to decrease earnings to pay less taxes or even pre recognise earnings during a period of tax exemptions (Healy and Wahlen 1999).

Therefore, research provides evidence on motivations of firms to engage in earnings management practices but limited research is undertaken concerning the nature of these practices and which specific accruals are managed.

\section{EARNINGS MANAGEMENT TECHNIQUES AND TYPES}

Earnings management can be classified into accruals earnings management, real earnings management, and classification shifting earnings management. Accruals earnings management manages earnings through practicing discretion on reporting accruals such as changing the timing of reporting revenues or expenses. Real earnings management depends on actual management decisions such as delaying research and development expenses. Classification shifting uses the way financial 
statements are presented in order to affect some certain figures such as classifying a discontinued item as income from continuing operations.

A long body of literature investigated the ways or techniques used to manage earnings. Many studies provided a review of these techniques (see for e.g. Ronen and Yaari 2008; Francis 2001). The following list represents some examples of these techniques:

- A choice or a change in accounting methods accepted under GAAP such as the choice between LIFO and FIFO or between straight-line depreciation and accelerated depreciation methods.

- A decision on the timing of the adoption of a new accounting standard.

- A decision or a change in accounting estimates such as depreciation, an allowance for bad debt (McNichols and Wilson 1988)and pension accounting.

- Transaction structuring in such a way to achieve some desired accounting treatment such as classifying leases as capital or operating leases.

- Timing the recognition of revenues and the capitalisation of expenses.

Levitt (1998) specifically addressed five methods of earnings management which are "big bath" restructuring charges, creative acquisition accounting, "cookie jar reserves", "immaterial" misapplications of accounting principles, and the premature recognition of revenues. Earnings management could be done using change of accounting policy such as the inventory valuation change from LIFO to FIFO or depreciation methods, manipulating accounting estimates such as estimation of the allowance for doubtful accounts, and timing of revenue and expense recognition. However, a change of accounting policy has to be disclosed according to the consistency principle which makes it an ineffective and costly method for earnings management (Healy and Wahlen 1999). Therefore, earnings management is expected to be undertaken using accounting estimates and timing of recognition that both can be thought of as accrual accounting.

As noted above, research on specific examples of how exactly managers manage earnings is quite limited in the literature despite the fact of how crucial these examples could be to the thorough understanding of the phenomena. Nelson et al. (2003) presented some examples from auditors' point of view on how earnings management is conducted in firms. Results were mixed between abusing the flexibility of GAAP and violating them. For instance, they presented practices such as recording sales of the next year in this period, bill and hold sales, abusing 
the right of return, and recording unreal sales. In addition, they have also discussed examples about abusing the matching concept and manipulating allowances.

\section{EARNINGS MANAGEMENT MITIGATION}

Based on the previous discussion in this study, we can conclude that earnings management, in general, tends to be undesirable as it distorts the financial reporting process and subsequently leads to lower earnings quality. Therefore, regulators have invested time and effort to seek solutions to this problem (Examples include regulations regarding auditor independence, audit firm tenure, auditing standards, and accounting standards). In addition, accounting and auditing research investigated factors and mechanisms, which lead to mitigate or constrain earnings management. There is no single accepted definition in the accounting literature for earnings management mitigation. However, the main point of earnings management mitigation is enhancing earnings quality and adding credibility and reliability to financial reporting. Therefore, earnings management mitigation may be defined as techniques, variables and procedures that could be used to constrain earnings management.

Jiambalvo (1996) argues that there are six factors, which will limit or may limit earnings manipulation. He listed them as auditing, internal control, governance structure, probability that manipulation will be observed, costs imposed when manipulation will be revealed, and prior managerial decisions. Moreover, Jiambalvo (1996) claims that little research investigated those factors. Consequently, a large number of studies started to investigate those factors. Moreover, the Sarbanes-Oxley act (2002) has enhanced many of these constraints such as putting limitations on auditor fees, limitations on board of directors, and audit committee. 


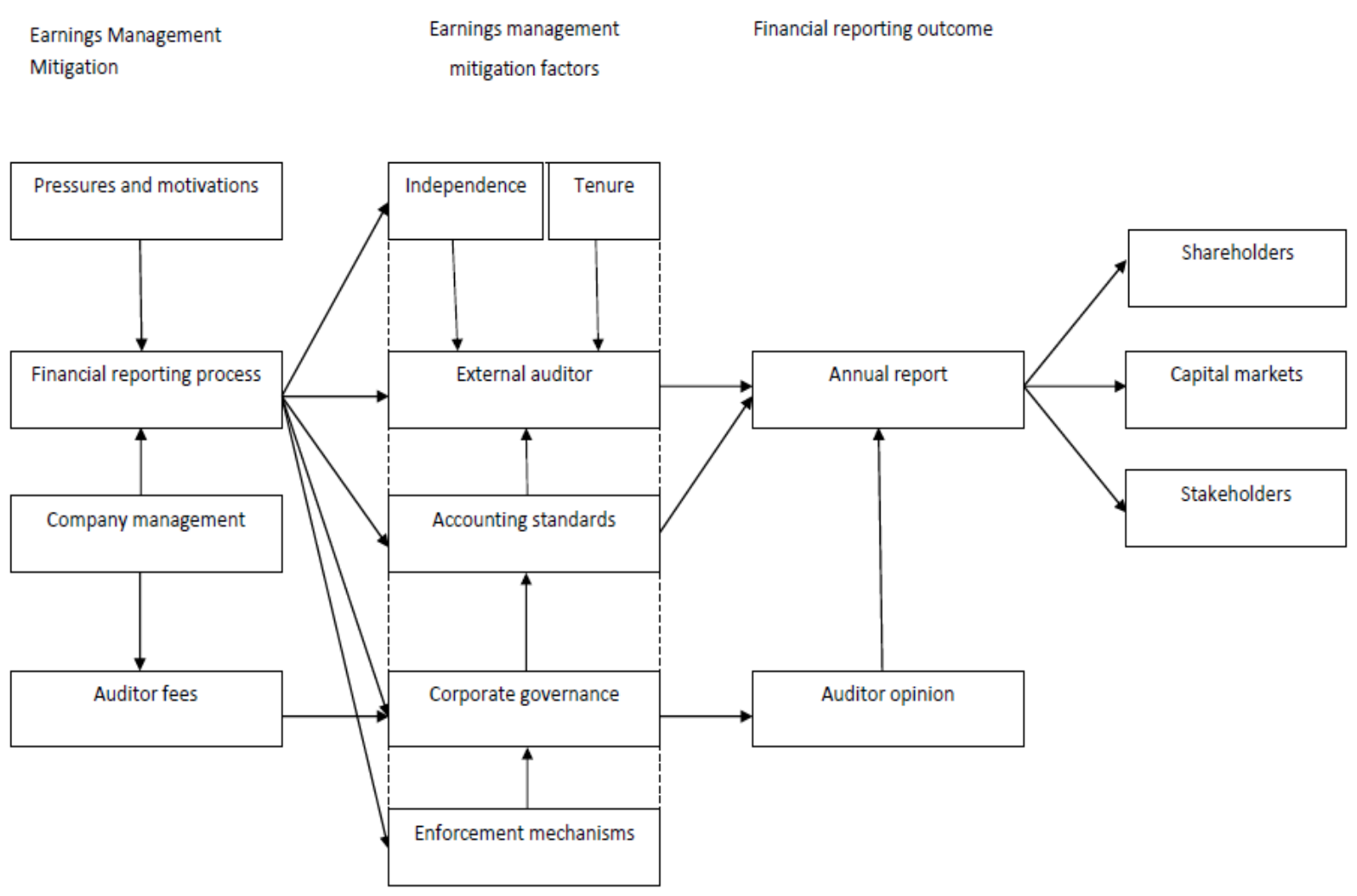

Figure 1: Earnings Management Mitigation

Based on the previous discussion, the authors prepared figure 1 which shows the interaction between parties involved in the financial reporting process where companies' managements prepare financial statements under some pressures to report a pre specified earnings figure due to the motivations and incentives mentioned earlier in this study. On the other hand, management of the company hires auditors to perform audit and non-audit services. Financial statements pass through some mitigation factors to approve or modify and constrain when earnings management is present. Those mitigation factors consist mainly of corporate governance factors (board of directors, audit committee, institutional shareholders, and others (Short et al. 1999)), external auditors, and accounting standards. In addition, accounting standards and corporate governance factors are affected by the enforcement mechanisms, which might differ across countries.

Auditors are affected by their independence and their behavior might differ depending on the length of the audit engagement (tenure). Furthermore, the output of the process is the annual report including the audit report, which investors, shareholders, and stakeholders in general use to make judgments about firm performance. Figure 1 shows the importance of depending on accurate and reliable financial information. This section provides a brief review of the literature of earnings management mitigation.

One main difference between the mitigation factors is the timing of the mitigation process. In other words, earnings management mitigation can occur in 
financial reporting process decisions (i.e., inside the company) by boards, audit committees, or institutional shareholders. On the other hand, the mitigation can occur by the auditor after the financial statements have been prepared.

\subsection{Corporate governance and investor protection}

Corporate governance mechanisms include mainly board of directors, institutional shareholders, audit committee, and external auditors. Prior research provides evidence that independent boards are less influenced by management, and thus more effective and that losses increase with board size (Fields and Keys 2003). Moreover, Vafeas (2000) tests whether an effective board structure will reduce the likelihood of earnings management. He argues that earnings will be more informative when board size is small and there are a high proportion of outside directors in place. He concludes that investors place a higher value on earnings for companies with a small board, but he is unable to detect any effect from the composition of the board itself.

In addition, Beasley (1996) finds evidence that a higher level of outside directors significantly reduces the probability of fraud in the presentation of financial statements. The study uses a matched sample design of 75 firms that had an occurrence of fraud during the period 1980-1991 with 75 fraud-free firms. The study concludes that the presence of outside directors increases board effectiveness in monitoring management activities. Finally, the study indicates that the presence of outside directors on the board is more important in reducing financial statement fraud than the board having an audit committee.

Another study by Klein (2002) provides evidence concerning board independence and earnings management. She finds that companies with independent boards and independent audit committees are much less likely to report abnormal accruals. Conversely, the highest levels of accruals occur for those companies where either the board or the audit committee has a majority of inside directors. Xie et al. (2003) report similar results with respect to the presence of earnings management and the independence of boards and audit committees. Their study also considers the financial sophistication of board members. The authors find that board and committee members with corporate and financial backgrounds are more often found at firms that report smaller discretionary accruals. Meeting frequency is another factor cited as contributing to less earnings management. Both of the above two studies provide strong evidence that independent and financially literate board members provide more effective monitoring of management activities, and specifically earnings management practices. In addition, Peasnell et al. (2005) find lower income-increasing earnings management for firms with a higher percentage of outside directors on their board. Furthermore, Habbash et al. (2011) suggest that not only the independence of directors but also their commitment that reduces earnings management. They found that board members commitment (measured by fees paid to non-executive directors) significantly results in lower levels of earnings management. 
Another issue of corporate governance is the existence of institutional shareholders in the ownership structure. The effect of institutional monitoring on earnings management will depend largely on the objective of investment. Little research has been conducted in this area and the results are still mixed. Some argue that institutional shareholders are mainly investing for short-term investment (An et al. 2016; Lel 2016; Sakaki et al. 2017). Therefore, they may actually influence companies to use positive accounting accruals. This is based on the belief that the stock market may not fully discount increased earnings that are due to earnings management, and that the institutions will sell their stocks before earnings are reversed or before the stock market fully acknowledges the transient nature of these earnings (Chung et al. 2002). However, others believe that institutional shareholders focus on long-term investment, which leads to discouraging firms' managers from using discretionary accruals and focus on long-term profitability. In addition, if shareholdings are high, institutional shareholders have the opportunity, resources, and the ability to monitor and influence managers of firms (Chung et al. 2002).

Chung et al. (2002) examine the influence of institutional investors on earnings management. Using a sample of 12,478 firm-years from 1988-1996, they measure discretionary accruals as a surrogate of earnings management using the modified Jones model. They find evidence that the presence of large institutional shareholdings decreases managers' potential for increasing or decreasing reported profits towards the managers' desired level of profits. Therefore, they conclude that the ability of managers to manage reported earnings is constrained by the effectiveness of external monitoring by institutional investors.

A third issue of corporate governance is the audit committee. For instance, Bedard et al. (2004) investigate whether the expertise, independence, and activities of a firm's audit committee have an effect on the quality of its financial reports. They examine the relationship between audit committee characteristics and the extent of earnings management as measured by the level of income-increasing and income-decreasing abnormal accruals. Using two groups of U.S. firms, one with relatively high and one with relatively low levels of abnormal accruals in the year 1996, they find a significant association between earnings management and audit committee governance practices.

More specifically, they find that aggressive earnings management is negatively associated with the financial and governance expertise of audit committee members, with indicators of independence, and with the presence of a clear mandate defining the responsibilities of the committee. The association is similar for both income-increasing and income-decreasing earnings management, suggesting that audit committee members are concerned with both types of earnings management and do not exhibit an asymmetric loss function similar to that of auditors. Klein (2002) finds a similar negative relation between audit committee independence and abnormal accruals. 


\subsection{Auditing}

There are two different points of view regarding earnings management mitigation where the key question is whether auditors along with other mitigation factors constrain earnings management. Firstly, auditors constrain managerial opportunism and therefore reduce distortion in earnings, resulting in a higher quality of reported earnings. Secondly, a different perspective assumes that auditors constrain managers' ability to communicate their private information because auditors have incentives to be conservative (Francis 2008). However, (Francis (2008) argues that benefits of constraining earnings management exceeds the associated costs.

Auditing aims at adding reliability and credibility to financial reporting which stakeholders seek in order to depend on the financial information contained in financial reports (Arens et al. 2005). However, the auditor's role faces a great deal of doubt especially after the collapses, which occurred in the U.S. at the beginning of this century. In this context, accounting and auditing research highlighted three points of view which are:

- Auditors are no longer able to detect earnings management practices which may be called the detection problem,

- Auditors are able to detect earnings management practices but they are not able to ask for modification or qualify their opinion as these practices appear to be within the boundaries of accounting standards which can be called the regulation problem, and finally

- Auditors are able to detect earnings management practices but they are motivated not to report them, by factors such as auditor's fees for example, which can be called the governance problem.

In addition, the effect of auditing on earnings management can also be grouped into two issues, which are detection and reporting. Audit quality is defined by DeAngelo (1981) as the "joint probability of detecting and reporting material misstatements in the financial statements". Prior studies (Caramanis and Lennox 2008; Francis and Yu 2009; Cahan and Sun 2015) argue that some factors such as audit quality, experience and effort lead to higher detection probability while other factors affect reporting such as accounting standards, audit and non-audit fees and auditor litigation. Finally, some variables such as audit tenure may affect detection ability through greater awareness of the client but may also affect reporting ability through building relationship with the client and the desire of keeping the client. It is important to know whether the problem lies in detection or in reporting or neither of them and this answer may differ across countries depending on the circumstances of each country. In the U.S., the problem is viewed more as a 
reporting problem, which can be understood in the light of the latest regulations, which attempt to enhance auditor independence.

Audit quality refers to whether audits are meeting or not meeting minimum legal and professional requirements. Moreover, audit quality is inversely related to audit failures which mean the higher the failure rate, the lower the quality of auditing (Francis 2004). Auditing is needed due to the conflict of interests between managers and other stakeholders as it reduces information asymmetries, which may exist by allowing outsiders to verify the validity of financial statements. As earnings management reduces information quality, researchers (Cahan and Sun 2015; Francis and Yu 2009; Caramanis and Lennox 2008; Krishnan 2003a) start examining the role of auditing effectiveness in mitigating earnings management. When effectiveness of an audit increases, the ability to detect earnings management attempts increases and so the auditor will ask for a modification of figures or may qualify his opinion when needed.

Becker et al. (1998) examine the effect of audit quality on earnings management. They use audit size as a proxy for audit quality following DeAngelo (1981), so they assume that big six auditors ${ }^{1}$ are of more quality than non-big six auditors and they use discretionary accruals as a proxy of earnings management. They test whether clients of non-big six auditors report discretionary accruals to increase net income relatively more than discretionary accruals reported by clients of non-big six auditors. Becker et al. (1998) use a sample of 10,379 firm years of clients of big 6 auditors and 2,179 firm years of clients of non-big six auditors for the period from 1989-1992. They conclude that clients of non-big six auditors report discretionary accruals of 1.5-2.1 percent of total assets higher than discretionary accruals reported by clients of big six auditors. They explain their findings by the assuming that lower audit quality is associated with accounting flexibility.

In addition, Francis et al. (1999) examined whether firms with a high propensity to generate high accruals tend to hire big auditors as big auditors are seen to give high quality audits and therefore can provide assurance that the high accruals are credible. They used a large sample of 74,390 firm year observations from 1975 to 1994 and they use operating cycle and capital intensity as proxies for propensity to generate accruals. They found that the likelihood of hiring big auditors is increasing in firms with an endogenous propensity of accruals. However, they found that firms audited by big auditors have lower discretionary accruals measured by both the Jones model and the modified Jones model, which enhances the belief of the positive effect of audit quality on mitigating earnings management.

\footnotetext{
${ }^{1}$ Big auditors were six at the time of this paper but they are now just big four. In this study, big auditors are used to represent big four, five, sex or even eight.
} 
Furthermore, Hussainey (2009) investigates the association between audit quality (financial statements are audited by the big four accounting firms) and earnings predictability (the investors' ability to anticipate future earnings). Based on a sample of 4,417 companies for the year ends during 1996-2002, he found evidence that earnings predictability is increased when companies' financial statements are audited by one of the big four accounting firms. However, these findings are not applicable for unprofitable firms. The findings of this study show that audit firm size (the big four versus non-big four) is a good proxy for the actual and perceived audit quality.

Another interesting auditing factor is audit effort. Research on the effect of audit effort on earnings management is relatively rare because of the difficulty of obtaining data about the number of audit hours performed for each audit engagement. Earnings management may be viewed in the context of a race between managers and auditors as many managers try to do creative accounting techniques and auditors are trying on the other side to detect those techniques. However, detection of earnings management attempts requires a great deal of experience and effort. Nonetheless, a negative relationship is expected between audit effort and earnings management.

Caramanis and Lennox (2008) attempted to measure this effect using a unique database of hours worked by auditors on 9,738 audits in Greece between 1994 and 2002. This is possible in Greece because audit firms in Greece are required to disclose the number of audit hours worked for each client to the professional accounting institute. They expect that greater audit effort will reduce managers' attempts to manage earnings. Therefore, they measure earnings management using the Jones model (1991) and find that (1) Abnormal accruals are more likely to be positive when audit hours are lower. (2) The magnitude of positive abnormal accruals is higher when audit hours are lower. They emphasize positive abnormal accruals rather than negative abnormal accruals because litigation risk is higher when clients manage earnings to report an increase in income rather than a decrease in income. However, they use the balance sheet approach to measure total accruals because it was not possible to use the cash flow statement approach as most Greek companies do not provide cash flow statements.

Caramanis and Lennox (2008) included some control variables in their model such as log of assets to control for client size, which is the most important factor in determining audit hours. They also included audit tenure, auditor change and debt financing variables. This study raises an important issue to regulators in other countries as to whether making disclosure of audit hours in audit report or determining guidelines for those hours might be helpful in mitigating earnings management. 
Nelson et al. (2002) examine how managers attempt to manage earnings and when do auditors prevent these attempts. They analyse 515 specific experiences from 253 auditors in which auditors believe that managers were trying to manage earnings. Data was collected through field-based questionnaire unlike most earnings management studies, which usually use abnormal accruals models to measure earnings management. Their results indicate that managers are more likely to attempt earnings management and auditors are less likely to require adjustments when the attempts are structured ${ }^{2}$ and standards are precise and when attempts are unstructured and standards are imprecise. Moreover, they conclude that managers are more likely to try to increase current period income. Results also indicate that auditors are more likely to ask for adjustments when attempts are material and auditors are more likely to require adjustments for lower size clients.

From the 515 earnings management attempts detected by auditors and analyzed in Nelson et al. (2002); 44\% agreed on over adjustment occurred, $21 \%$ no adjustment is made because attempts are in accordance with accounting standards. In addition, $17 \%$ made no adjustment because the auditor could not prove that the client position was improper, $18 \%$ no adjustment is made because attempts are immaterial, and finally around $1 \%$ of the cases (just 7 cases out of 515) where the client received a modified audit opinion, which means that more than $99 \%$ of the cases have been solved before reporting.

Nelson et al. (2003) analyzed the same sample used in Nelson et al. (2002) to gain a better understanding as to which methods managers use to manage earnings. The results indicate $53 \%$ of the attempts aimed to increase current year income, $31 \%$ aimed to decrease current year income, $16 \%$ have no clear effect on current year income and expense recognition was the most used approach to manage earnings.

Krishnan (2003b) tests the association between auditor industry expertise and earnings management and hypothesizes that auditors' industry expertise will constrain earnings management. He uses auditor market share in an industry and industry's share in auditor portfolio of client industries as proxies of auditor industry expertise because it is an unobservable variable. Moreover, he measures earnings management as the absolute value of discretionary accruals estimated using the cross-sectional version of the Jones model. Based on a sample of 24,114 firm-year observations representing 4,422 firms for the period from 1989 to 1998, Krishnan (2003b) concludes that clients of non-specialist auditors report absolute discretionary accruals that on average are 1.2 percent higher than the discretionary accruals reported by clients of specialist auditors. The results support the notion

\footnotetext{
2 A structured transaction occurs when managers are attempting to manage earnings through modifying contracts or activities to fit with respect with a specific standard.
} 
that auditor industry expertise enhances earnings quality through mitigating earnings management.

Francis and Krishnan (1999) test the effect of accounting accruals on auditor opinion as they hypothesise that those firms with high accruals are more likely to receive modified audit opinion. Auditors tend to do so as a compensation of the greater uncertainty and therefore their exposure to greater risk of type two errors ${ }^{3}$, which is highly correlated to the probability of auditor litigation. They use a sample of 2,608 observations for the years 1986-1987 and find empirical evidence that firms with higher accruals are more likely to receive modified audit opinion, which is called auditor reporting conservatism. However, their results hold for non-big six auditors as only big six auditors show evidence of reporting conservatism.

A final key issue in the effect of auditors in mitigating earnings management is auditor independence. Auditor independence consists of two parts; independence in fact and independence in appearance. Previous studies test whether auditor independence is compromised because of auditors' provision of non-audit services. Auditor independence in fact is often measured by the magnitude of earnings management the auditor will allow in the financial statements. On the other hand, independence in appearance is measured by investors' responses to higher than expected non audit services' fees which might be perceived by investors to lead to compromising auditor independence and is usually reflected in stock prices (Fearnley and Beattie 2004).

Results of prior studies provide evidence on the effect of auditor fees especially non audit fees on auditor independence in appearance (e.g. Lim and Tan 2008; Frankel et al. 2002). However, results on auditor independence in fact are mixed. Firstly, some studies provide evidence that non audit fees lead to independence being compromised (Frankel et al. 2002) but also counter evidence is reported (Ashbaugh et al. 2003). Secondly, some studies provide evidence that audit fees represent more effort and, therefore, enhance auditor independence (Antle et al. 2006).

\subsection{Accounting and auditing regulations}

Despite the fact that earnings management has caused a great deal of criticism of auditors through the public media, auditing standards setters do not mention any new standards for earnings management in specific. The latest professional announcement on a related issue is the statement on auditing standards (SAS) no. 99 issued by the Auditing Standards Board (ASB) in the US, which was a modification to the earlier SAS 82 considering fraud in the financial statements audit. In addition, no official pronouncements have been issued by the International Auditing Standards Board (IASB) except a similar standard on Fraud

\footnotetext{
${ }^{3}$ Type two errors occur when auditors fail to modify their opinions in cases where they should do.
} 
no. 240. One important question is why the official professional bodies do not mention earnings management? Do professional bodies consider earnings management as fraud? Alternatively, do they consider it acceptable? However, SAS 99 was mainly issued as a response to the scandals that occurred in the U.S. and as a response to the Sarbanes-Oxley act of 2002. This means that professional bodies care about fraud more than they care about earnings management or they consider any manipulation in earnings as fraud if it misleads investors or distorts financial reporting and consequently causes a decline in earnings quality.

A number of recent auditing standards have been issued or modified recently to enhance the credibility of financial reporting. For instance, the new international auditing standard (IAS) number 540 dealing with auditing accounting estimates replaced the old one. Moreover, IAS 240 concerned with the auditor responsibility to consider fraud in an audit of financial statements was modified.

A central question in this area concerns with auditor's responsibility of earnings management practices whether within GAAP or outside GAAP. All professional auditing standards are concerned with the possibility of the existence of material misstatements in financial statements. However, earnings management causes misstatements in financial reporting and therefore, We argue that auditors are just as responsible for earnings management as they are for fraud.

Another important regulation was the issuance of the Sarbanes-Oxley act (2002) which is considered one of the most important laws in the US since the SEC law of 1934. The law was introduced because of the scandals, which occurred in the US in 2000 and 2001. The law has adopted some mechanisms that enhance the credibility of financial reporting and aim mainly at restoring investor confidence in capital markets. Articles of the law prohibit auditors from providing any additional services to clients such as bookkeeping, accounting information systems design, and expert services. The logic behind this prohibition is to enhance auditors' independence and decrease the power of the economic bond between clients and auditors.

In addition, the law also increases the criminal penalty if auditors were involved in fraudulent financial reporting to prison of 10 years instead of 5 and also increases the financial penalty which enhances the notion that auditor litigation could lead to less earnings management (Heninger 2001). Arthur Andersen, the famous auditing firm and one of the previous big five auditors, was subject to penalties before the new law as a result of its involvement in fraud in the auditing of Enron, WorldCom, and others. Moreover, the law determines a mandatory rotation of audit partners every five years. Limiting audit tenure was decided in order to decrease possibility of auditors being too tolerant to earnings management practices after spending a long period of time with the same clients. Audit tenure 
may create some kind of personal relationship between auditors and top managers of the client.

Furthermore, auditors in the US are prohibited from providing many non-audit services according to the Sarbanes-Oxley act, 2002. However, their counterparts in the UK are allowed to provide such services. Therefore, the US system deals with the threat to auditor independence through banning auditors from providing non audit services, while the UK system faces the problem through mandating detailed disclosure of all kinds of fees paid by the client to the auditor. Moreover, according to the Combined Code (2006), the audit committee is responsible for assessing whether fees paid to the auditor may create an economic bonding and compromise auditor independence.

As to the disclosure of compliance with corporate governance rules, UK companies must disclose in their annual reports corporate governance information based on comply or explain. However, US companies have no option but to comply mainly because the UK corporate governance Combined Code is considered a code of best practise whereas US corporate governance rules are mainly based on Sarbanes-Oxley act. Interestingly, the percentage of compliance of UK large companies is quite high because the logic of the Combined Code is to encourage good corporate governance practice through which companies may have comparative advantage over non-compliance companies which may enhance a good reputation and capital market status. On the other hand, US companies have to apply the law, which leave no chance for improvements.

In addition, audit reports of financial statements prepared under US GAAP should state clearly if preparation is done in accordance or conformity with GAAP. However, UK GAAP and IFRS require the financial statements to provide a true and fair view with no reference to specific standards. Therefore, it might be expected to find US managers managing earnings through structuring transactions to cope with a specific standard whereas UK managers might attempt to manage earnings through using the flexibility of accounting standards. The accounting literature provides very little evidence on which type of standards yield better earnings quality - most studies on this issue are descriptive studies or based on questionnaires.

Accounting standards tend to be more rules based if they determine every detail and treatment to be followed like the case of US GAAP (Nobes 2009; Jeanjean and Stolowy 2008; Barth et al. 2008; Psaros 2007; Goncharov and Zimmermann 2006; Nobes 2005). However, they tend to be more principles based if they determine the major objective of the standard and leave space for professional judgment to be exercised. The Sarbanes-Oxley Act (2002) requires the SEC to study the feasibility of shifting to a more principles-based financial reporting system. Earnings management seems to arise mainly because of the 
flexibility of accounting standards. Therefore, is it better to use rules-based standards, which leave no space for professional judgment? Alternatively, is it better to depend on principles-based standards, which leave space to exercise professional judgment? We conducted the following comparison between the two types of GAAP as follows:

Table 1: Comparison between the two types of accounting standards

\begin{tabular}{||l|l|l||}
\hline Characteristics & $\begin{array}{l}\text { Principles-based } \\
\text { standards }\end{array}$ & $\begin{array}{l}\text { Rules-based } \\
\text { standards }\end{array}$ \\
\hline Relevance & More relevant & Less relevant \\
\hline Reliability transaction & Less reliable & More reliable \\
\hline $\begin{array}{l}\text { Opportunity } \\
\text { structuring }\end{array}$ & Lower & greater \\
\hline Details of the standard & Less details & More details \\
\hline Professional judgment of requesting & More & Lower \\
\hline $\begin{array}{l}\text { Likelihood } \\
\text { modification by the auditor }\end{array}$ & Greater \\
\hline Application cost & Less costly & More costly \\
\hline
\end{tabular}

\section{CONCLUSION}

This study has presented a brief overview of the earnings management literature. The paper discussed the definitions of earnings management and conclude that earnings management is undesirable and should be mitigated or eliminated if possible. The study also provided a theoretical explanation of the issue through a discussion of agency theory and stewardship theory. In addition, we provided some examples of the motivations and incentives, which may lead to attempts of a company's management to report a pre-specified income figure. Furthermore, we also discussed some of the techniques and types of earnings management illustrated in prior research.

Moreover, the paper has provided a review of the literature about earnings management mitigation. The main point of earnings management mitigation is enhancing earnings quality and adding credibility and reliability to financial reporting. Accounting and auditing research investigated factors and mechanisms, which lead to mitigate or constrain earnings management. Those mitigation factors consist mainly of corporate governance factors (board of directors, audit committee, institutional shareholders, and others), external auditors, and accounting standards. In addition, accounting standards and corporate governance factors are affected by the enforcement mechanisms, which might differ across countries. One main difference between the mitigation factors is the timing of the mitigation process. In other words, earnings management mitigation can occur in financial reporting process decisions (i.e., inside the company) by boards, audit 
committees, or institutional shareholders. On the other hand, the mitigation can occur by the auditor after the financial statements have been prepared.

This prior discussion revealed two important issues. Firstly, limited research has been devoted to assess the validity of some regulations aiming at constraining earnings management. Further research is needed to assess regulation regarding auditor fees, audit firm and partner tenure, and the impact of the transition to International Financial Reporting Standards (IFRS) on earnings management. Secondly, income increasing earnings management is relatively more important than income decreasing earnings management. 


\section{References}

Abed, S., A. Al-Attar, and M. Suwaidan. 2012. Corporate governance and earnings management: Jordanian evidence. International Business Research 5 (1):216.

An, Z., D. Li, and J. Yu. 2016. Earnings management, capital structure, and the role of institutional environments. Journal of Banking \& Finance 68:131-152.

Antle, R., E. Gordon, G. Narayanamoorthy, and L. Zhou. 2006. The joint determination of audit fees, non-audit fees, and abnormal accruals. Review of Quantitative Finance and Accounting 27 (3):235-266.

Arens, A. A., R. J. Elder, and M. S. Beasley. 2005. Auditing and assurance services : an integrated approach. International ed., 10th ed. ed. Upper Saddle River, N.J. ; [Great Britain]: Pearson Education International/ Prentice Hall.

Ashbaugh, H., R. LaFond, and B. W. Mayhew. 2003. Do Nonaudit Services Compromise Auditor Independence? Further Evidence. Accounting Review 78:611-639.

Barth, M. E., W. R. Landsman, and M. H. Lang. 2008. International Accounting Standards and Accounting Quality. Journal of Accounting Research 46 (3):467-498.

Beasley, M. S. 1996. An Empirical Analysis of the Relation Between the Board of Director Composition and Financial Statement Fraud. Accounting Review 71 (4):443-465.

Becker, C. L., M. L. Defond, J. Jiambalvo, and K. R. Subramanyam. 1998. The effect of audit quality on earnings management. Contemporary Accounting Research 15 (1):1-24.

Bedard, J., S. M. Chtourou, and L. Courteau. 2004. The Effect of Audit Committee Expertise, Independence, and Activity on Aggressive Earnings Management. Auditing 23 (2):3-3.

Cahan, S. F. 1992. The Effect of Antitrust Investigations on Discretionary Accruals: A Refined Test of the Political-Cost Hypothesis. Accounting Review 67 (1):77-95.

Cahan, S. F., and J. Sun. 2015. The effect of audit experience on audit fees and audit quality. Journal of Accounting, auditing \& finance 30 (1):78-100.

Caramanis, C., and C. Lennox. 2008. Audit effort and earnings management. Journal of accounting and economics 45 (1):116-138.

Chi, C. W., K. Hung, H. W. Cheng, and P. T. Lieu. 2015. Family firms and earnings management in Taiwan: Influence of corporate governance. International Review of Economics \& Finance 36:88-98.

Chung, R., M. Firth, and J.-B. Kim. 2002. Institutional monitoring and opportunistic earnings management. Journal of corporate finance 8 (1):29-48.

Davis, J. H., F. D. Schoorman, and L. Donaldson. 1997. Toward a Stewardship Theory of Management. The Academy of Management Review 22 (1):20-47.

DeAngelo, L. E. 1981. Auditor size and audit quality. Journal of Accounting and Economics 3:183-199.

Dechow, P. M., and D. J. Skinner. 2000. Earnings Management: Reconciling the Views of Accounting Academics, Practitioners, and Regulators. Accounting Horizons 14 (2):235250.

Fama, E. F., and M. C. Jensen. 1983. Separation of Ownership and Control. Journal of Law and Economics 26 (2):301-325.

Fearnley, S., and V. Beattie. 2004. The Reform of the UK's Auditor Independence Framework after the Enron Collapse: An Example of Evidence-based Policy Making. International Journal of Auditing 8 (2):117-138.

Fields, M. A., and P. Y. Keys. 2003. The Emergence of Corporate Governance from Wall St. to Main St.: Outside Directors, Board Diversity, Earnings Management, and Managerial Incentives to Bear Risk. The Financial Review 38 (1):1-24.

Fields, T. D., T. Z. Lys, and L. Vincent. 2001. Empirical research on accounting choice. Journal of Accounting and Economics 31 (1-3):255-307. 
Francis, J. 2001. Discussion of empirical research on accounting choice. Journal of Accounting and Economics 31 (1-3):309-319.

Francis, J. R. 2004. What do we know about audit quality? The British Accounting Review 36 (4):345-368.

- 2008. Understanding and Researching Audit Quality. In IV Accounting Research Symposium, Current Trends in Accounting Research Amsterdam Business School

Francis, J. R., and J. Krishnan. 1999. Accounting Accruals and Auditor Reporting Conservatism. Contemporary Accounting Research 16:135-165.

Francis, J. R., E. L. Maydew, and H. C. Sparks. 1999. The role of Big 6 auditors in the credible reporting of accruals. Auditing 18 (2):17.

Francis, J. R., and M. D. Yu. 2009. Big 4 office size and audit quality. The Accounting Review 84 (5):1521-1552.

Frankel, R. M., M. F. Johnson, and K. K. Nelson. 2002. The Relation between Auditors' Fees for Nonaudit Services and Earnings Management. Accounting Review 77 (4):71.

Frantz, P. 1997. Discretionary Accounting Choices: A Debt-covenants Based Signalling Approach. Accounting \& Business Research 27 (2):99-110.

Goncharov, I., and J. Zimmermann. 2006. Do Accounting Standards Influence the Level of Earnings Management? Evidence from Germany. SSRN eLibrary.

Habbash, M., A. Salama, R. Dixon, and K. Hussainey. 2011. The effects of non-executive directors' commitment, chairman independent and ownership structure on earnings management. Journal of Applied Accounting Research forthcoming.

Healy, P. M. 1985. The effect of bonus schemes on accounting decisions. Journal of Accounting and Economics 7 (1-3):85-107.

Healy, P. M., and J. M. Wahlen. 1999. A Review of the Earnings Management Literature and Its Implications for Standard Setting. Accounting Horizons 13 (4):365-383.

Heninger, W. G. 2001. The association between auditor litigation and abnormal accruals. The Accounting Review 76 (1):111.

Hussainey, K. 2009. The impact of audit quality on earnings predictability. Managerial Auditing Journal 24 (4):340-351.

Jaggi, B., and L. Picheng. 2002. Earnings Management Response to Debt Covenant Violations and Debt Restructuring. Journal of Accounting, Auditing \& Finance 17 (4):295-324.

Jeanjean, T., and H. Stolowy. 2008. Do accounting standards matter? An exploratory analysis of earnings management before and after IFRS adoption. Journal of Accounting and Public Policy 27 (6):480-494.

Jensen, M. C., and W. H. Meckling. 1976. Theory of the firm: Managerial behavior, agency costs and ownership structure. Journal of Financial Economics 3 (4):305-360.

Jiambalvo, J. 1996. Discussion of "Causes and consequences of earnings manipulation: An analysis of firms subject to enforcement actions by the SEC". Contemporary Accounting Research 13 (1):37.

Jones, J. 1991. Earnings Management during Import Relief Investigations. Journal of Accounting Research 29:193-228.

Kaplan, R. S. 1985. Evidence on the effect of bonus schemes on accounting procedure and accrual decisions. Journal of Accounting and Economics 7 (1-3):109-113.

Klein, A. 2002. Audit committee, board of director characteristics, and earnings management. Journal of Accounting and Economics 33 (3):375-400.

Krishnan, G. V. 2003a. Does Big 6 auditor industry expertise constrain earnings management? Accounting horizons 17:1.

Krishnan, G. V. 2003b. Does Big 6 Auditor Industry Expertise Constrain Earnings Management? Accounting Horizons 17:1-16.

Lel, U. 2016. The role of foreign institutional investors in restraining earnings management activities across countries. 
Levitt, A. 1998. The numbers game. The CPA Journal 68 (12):14-19.

Lim, C.-Y., and H.-T. Tan. 2008. Non-audit Service Fees and Audit Quality: The Impact of Auditor Specialization. Journal of Accounting Research 46 (1):199-246.

McNichols, M., and G. P. Wilson. 1988. Evidence of Earnings Management from the Provision for Bad Debts. Journal of Accounting Research 26 (3):1-31.

Muth, M., and L. Donaldson. 1998. Stewardship theory and board structure: A contingency approach. Corporate Governance: An International Review 6 (1):5-28.

Nelson, M. W., J. A. Elliott, and R. L. TarpIey. 2002. Evidence from Auditors about Managers' and Auditors' Earnings Management Decisions. Accounting Review 77 (4):175.

Nelson, M. W., J. A. Elliott, and R. L. Tarpley. 2003. How Are Earnings Managed? Examples from Auditors. Accounting Horizons 17:17-35.

Nobes, C. W. 2005. Rules-Based Standards and the Lack of Principles in Accounting. Accounting Horizons 19 (1):25-34.

- 2009. Observations on measuring the differences between domestic accounting standards and IAS. Journal of Accounting and Public Policy 28 (2):148-153.

Parfet, W. U. 2000. Accounting Subjectivity and Earnings Management: A Preparer Perspective. Accounting Horizons 14 (4):481-488.

Peasnell, K. V., P. F. Pope, and S. Young. 2005. Board Monitoring and Earnings Management: Do Outside Directors Influence Abnormal Accruals? Journal of Business Finance \& Accounting 32 (7-8):1311-1346.

Prencipe, A., G. Markarian, and L. Pozza. 2008. Earnings management in family firms: Evidence from R\&D cost capitalization in Italy. Family Business Review 21 (1):71-88.

Psaros, J. 2007. Do principles-based accounting standards lead to biased financial reporting? An Australian experiment. Accounting \& Finance 47 (3):527-550.

Ronen, J., and V. Yaari. 2008. Earnings management : emerging insights in theory, practice, and research. New York: Springer.

Sakaki, H., D. Jackson, and S. Jory. 2017. Institutional ownership stability and real earnings management. Review of Quantitative Finance and Accounting 49 (1):227-244.

Saleh, N. M., and K. Ahmed. 2005. Earnings management of distressed firms during debt renegotiation. Accounting \& Business Research 35 (1):69-86.

Schipper, K. 1989a. Commentary on earnings management. In Accounting Horizons, 91-102.

Schipper, K. 1989b. Earnings management. Accounting horizons 3 (4):91.

Shivakumar, L. 2000. Do firms mislead investors by overstating earnings before seasoned equity offerings? Journal of Accounting \& Economics 29 (3):339-371.

Short, H., K. Keasey, M. Wright, and A. Hull. 1999. Corporate governance: from accountability to enterprise. Accounting \& Business Research 29 (4):337-352.

Teoh, S. H., W. Ivo, and T. J. Wong. 1998a. Earnings management and the long-run market performance of initial public offerings. Journal of Finance 53 (6):1935.

Teoh, S. H., I. Welch, and T. J. Wong. 1998b. Earnings management and the underperformance of seasoned equity offerings. Journal of Financial Economics 50 (1):63-99.

Vafeas, N. 2000. Board structure and the informativeness of earnings. Journal of Accounting and Public Policy 19 (2):139-160.

Watts, R. L., and J. L. Zimmerman. 1986. Positive accounting theory. London: Prentice Hall International.

1990. Positive Accounting Theory: A Ten Year Perspective. Accounting Review 65 (1):131-156.

Xie, B., W. N. Davidson, and P. J. DaDalt. 2003. Earnings management and corporate governance: the role of the board and the audit committee. Journal of Corporate Finance 9 (3):295-316. 